\title{
Increasing Consumer Purchase Intention Through Private Label of Grocery: Empirical Evidence of Indonesian Consumers
}

\author{
$1^{\text {st }}$ Sukaris Sukaris \\ Faculty of Economics and Business, \\ Universitas Muhammadiyah Gresik. \\ Gresik, Indonesia \\ sukaris@umg.ac.id \\ $4^{\text {th }} \mathrm{Al}$ Kusani \\ Faculty of Economics and Business, \\ Universitas Muhammadiyah Gresik. \\ Gresik, Indonesia s
}

\author{
$2^{\text {nd }}$ Fitri Dahlia \\ Faculty of Economics and Business, \\ Universitas Muhammadiyah Gresik. \\ Gresik, Indonesia \\ $5^{\text {th }}$ Ahmad Qoni Dewantoro \\ Faculty of Economics and Business, \\ Universitas Muhammadiyah Gresik. \\ Gresik, Indonesia
}

\author{
$3^{\text {rd }}$ Budiyono Pristyadi \\ Faculty of Economics and Business, \\ Universitas Muhammadiyah Gresik. \\ Gresik, Indonesia
}

\begin{abstract}
The use of brands in products today is dominated by manufacturing brands compared to private label products, however the use of private labels is becoming a trend among retailers in Indonesia, especially private label on grocery products for daily needs. This use for retailers has a double meaning that is one side as a way to win competition for retailers, one side is the use of private label as an attraction for consumers. The purpose of this study was to determine the increased interest in purchasing grocery's private label products through perceived quality, perceived risk, packaging, store image and familiarity. The total sample consisted of 200 respondents who bought private label brands. Hypotheses are tested using multiple linear regression analysis modelling. The results of the regression show that perceived quality, perceived risk, store image and familiarity can increase purchase intentions on grocery's private label products. This paper first explicitly examines the impact of the use of private label for the purchase of Indonesian consumers, especially grocery products.
\end{abstract}

Keywords-Private Label, Perceived Quality, Perceived Risk, Product Packaging, Store Image, Familiarity, Purchase Intention

\section{INTRODUCTION}

Retail growth in Indonesia today is said to have decreased and slowed by $1 \%$ in 2018 compared to last year which grew by around $1 \%-2.5 \%$. But despite the decline in retail growth, not a few people visit supermarkets because of the wide variety of products offered. With this decline modern retail requires effort and innovation such as intensifying promotions and increasing the quality of products offered both in terms of composition and packaging (packaging) but also with prices that can compete with competitors (ww.detik.com 2018).

Indonesia has a number of large retailers such as Carrefour, Alfamart, Indomaret, Giant, Matahari Departement Store and others that offer good facilities for supplying family needs and even food \& beverages. Giant Hypermarket is a subsidiary of PT Hero Supermarket Tbk, which is one of the supermarkets largest in Indonesia. Founded in 1971 which is predicted to be the first retailer in Indonesia. Giant's first store in Indonesia was opened in 2002. In 2017 the PT Hero Supermarket Tbk Group stores around 450 outlets, each consisting of 1 IKEA outlet, 250 Guardian outlets, 108 outlets Giant Ekspress, 32 Hero Supermarkets, 57 Giant Extra outlets and 2 Giant Mart outlets (Katadata.co.id 2018). Giant is intended to serve the people in Indonesia with cheap products and prices. Giant Ekspress focuses on providing products such as meat, seafood and fresh household products and general goods (www.giant.co.id 2018).

The growth of modern retail in Indonesia is also followed by the growth of private label in Indonesia. [1] stated that private label brands are brands that are managed and owned by certain retailers. [2], [3] private label known as its own brand, store brand, retail brand, and generally refers to brands owned, controlled and sold exclusively by retailers. This is done by retail companies that may prefer to use store names for private label products or alternatively they create individual brands. In addition, retailers can get the opportunity to capture more consumers by providing relatively cheaper private label products and consumers easily reach products at retail stores. 
Previous studies have shown that private label brand products have positive consequences including there are links with consumer purchasing decisions such as [2], [4][6].

Products are Private label a trend among retailers in Indonesia, but their use is still low in Indonesian consumers compared to manufacturer's labels. This is because that consumers in Indonesia are still included in the category loyal brand. Consumers in Indonesia are more accustomed to buying manufacturer's label products than products private label. The Nielsen Global Research survey states that $50 \%$ of consumers in Indonesia are still loyal to non- private label products and in terms of quality $43 \%$ say they do not like the quality of products private label or consider quality low. So consumers in Indonesia have a poor perception of products private label and not a few who prefer to buy manufacturer's label products advertised on television in general.

But the phenomenon that is seen in the purchase of private labels on Giant Exspress Gresik occurs in products Grocery (groceries) especially rice and sugar products are more in demand by consumers than products 's label manufacturing competitor. This shows that customers or consumers in Giant Express Gresik refute the phenomenon, because the interest in private label is quite good. The selection of objects based on Giant Exspress is a retail that is often visited by consumers, especially in terms of shopping for groceries on a larger scale when compared to other retailers and products private label Giant are the ones that appeared earlier since 2003 using the Giant and First Choice brands rather than Other retail competitors, such as Indomaret, issued their private label around 2005.

Based on the problem formulation, the purpose of this study is The purpose of this study was to determine the increased interest in purchasing grocery's private label products through perceived quality, perceived risk, packaging, store image and familiarity.

\section{LITERATURE REVIEW}

\section{A. Purchase Intention}

Purchase intention as the probability of consumer's readiness to purchase a product in near future. It is generally linked with the consumers' attitude, perception and buying behavior[7]. Purchase Intention illustrates a possibility that consumers will plan or be willing to buy certain products or services in the future. Increased buying interest shows an increase in the likelihood of a purchase. When a consumer has a positive buying interest, it will form a commitment to a brand that will encourage consumers to make an actual purchase[7].

\section{B. Perceived quality}

The perceived quality refers to consumer's perception of the overall quality or superiority of the product or service regarding the intended purpose. Quality perception cannot be determined objectively, because quality perception is a perception and also involves what is desired and important for the customer. [8] states that perceived quality as a consumer's assessment of a superiority or overall product superiority. This can happen when consumers see a brand has better quality then the attitude towards the brand is also getting better.

[9] states that an indicator of perceived quality is a reliable product, a product that provides consistent value and good quality. While [2] gives a measure of quality products that are of high quality, superior products and these products are of very good quality. Quality products for consumers are products that provide value, and from the value obtained, consumers will conduct good buying, loyalty and recommendation behaviors to others [10]

\section{Perceived Risk}

The perceived risk perception is the uncertainty faced by customers when they cannot see or know the consequences of their purchasing decisions. This definition highlights two relevant dimensions of perceived risk: uncertainty and consequences. The level of risk that is accepted by consumers themselves to take risks are the factors that influence their purchasing strategies. It must be emphasized that consumers are influenced by risks they understand, whether those risks really exist or not. Risk is not felt-no matter how real it will not affect consumer behavior. Although sometimes the risk for consumers is also sought, for example, such as tourist products [11]. [12], [13] states that perceived risk is defined as the desired performance uncertainty experienced by all customers when making a purchasing decision. [9] provides information on several indicators of perceived risk among them worried about using the wrong money, worried that the brand purchased will not be as good as other brands, worry that products aren't as safe as other brands, worry about what their families might think, worry about what their friends might think, and worry that products purchased might not be consistent with their selfimage.

\section{The Product Packaging}

Packaging is one of the main factors of a product in purchasing decision making at the point of purchase[14]. Packaging is defined as the science, art and technology of a protected product[15]. Therefore, product packaging can cover the science, art and technology of design and production of packaging for a product. Product packaging has three main functions: protection of its content, provision of information and product differentiation from other products through consumer interest. [16] declare there are various factors that influence consumer purchasing behavior such as: packaging color, wrapper design, print information, background image, packaging material, and innovation. The function of packaging at this time has changed in line with changes in style and lifestyle of consumers who tend to be self-service. Packaging (packaging) serves as a means of sales promotion that can stimulate consumer spending habits in order to reduce the high cost of promotion[17]

\section{E. Store Image}

Store image is the consumer's perception of all the attributes associated with the store. [18] states the store's image as an overall impression represented by the perceived memory associated with outlets or retail which are both related to consumer memory. Retail stores or retailers have their own store image which helps influence 
the quality of a product and also influences consumers to choose where they will shop. Factors that influence the store image such as merchandise, store atmosphere, store personnel[19], while [20] state the store image includes the dimensions of the store image has been centered on factors such as quality and variety of products sold, product prices, physical store facilities, and services provided by personal sales. Thus if the image of a store or company gets better it will be able to improve consumer purchasing decisions [21]

F. Familiarity

Familiarity by [22]is how big the brand associated directly or indirectly with the experience possessed by the consumer. The experience of the brand itself can be obtained from advertising media exposure about the brand, brand exposure in a store, and the purchase or use of brands that can increase familiarity.

Brand familiarity for consumers as the best known brand or for consumers already familiar with a brand, this will make consumers usually tend not to evaluate the quality of the product and have the intention to buy more. Likewise, if consumers are faced with several choices, consumers will choose products that are already known before.

[23] defines familiarity as knowledge of what, why, where, and when other people do what they did before. That familiarity with a brand not only reflects the overall consumer experience with the brand, but also relates to the brand image and use of the brand itself.

\section{MATERIAL FRAMEWORK AND METHODS}

This study uses a quantitative approach, which can be interpreted as a research method based on the philosophy of positivism used to examine a particular population or sample. Sampling techniques are generally carried out randomly, data collection using research instruments, quantitative / statistical data analysis with the aim to test the hypotheses.

This research was conducted at the Giant Exspress, Gresik Kota Baru branch. East Java The object of this research is visitors and buyers of Giant grocery private label products.

This study uses a method non probability sampling, which is a sampling technique that does not provide the same opportunities / opportunities for each element or population member to be selected as a sample. While the sample used in this study was a portion of the visitors of the Giant Express Gresik branch of the new city who bought private label products, in this study the samples used were 200 respondents. The procedure used in sampling in this study is a accidental sampling. Sampling which technique based on coincidence, ie anyone who accidentally meets the researcher can be used as a sample, when viewed by people who are met it is suitable as a source of data.

Data collection techniques in this study were the distribution of questionnaires. The questionnaire will be distributed to consumers in private label Giant the Gresik Kota Baru branch, especially those who buy Grocery
"Giant" products. The questionnaire is a data collection buckle given to respondents with written questions to answer.

Data analysis is grouping data based on variables, presenting data for each variable examined, doing calculations to answer the problem formulation and calculating to test the hypotheses that have been proposed. Multiple linear regression analysis is observational data usually not only based on one variable but by several or even many variables.

\section{RESULTS AND DISCUSSION}

A. Characteristics of Respondents by Age

Researcher presents the characteristics of respondents by age apart by sex for 200 respondents, it can be concluded that the age range of respondents at the age of 17-21 years as many as 20 people while the age range 2226 was 30 people, range $27-31$ years was 40 people, while the age range of respondents was $32-36$ as many as 35 people, ages 37-41 as many as 35 people, 42 - 46 as many as 15 , while aged $47-51$ years as many as 20 people and 52-56 as many as 5 people.

\section{B. Characteristics of Respondents by Gender}

Description of characteristics in this study has the function of knowing the characteristics of each respondent in general. The researcher presents the characteristics of the respondents identified by gender and age range. The results known that the number of respondents is 200 of which 45 are men and 155 are women.

C. Instrument Test

Validity Test is used to measure the validity of a questionnaire. The questionnaire is said to be valid if the items from a questionnaire are able to reveal something that will be measured by the questionnaire. The accuracy of the measurement scale is a requirement that must be met so that further testing can be done. The accuracy of the scale shows that each indicator formulated has the same basic factors. That the question items are able to measure the construct measured, with the value of the item having the above correlation 0.50 [24]. so all question items contained in the questionnaire from the independent and dependent variables the results prove to be valid.

Researchers measure the reliability of a variable by looking at Cronbach Alpha with a significance value used greater than 0.60. A construct or variable is said to be reliable if it gives a value Cronbach Alpha > 0.60 (Gliem and Gliem, 2003; Maholtra, 1996). The results shows that the independent and dependent variables have value Alpha Cronbach (a)> 0.60 or greater than 0.60. So the questions contained in the questionnaire were declared reliable.

\section{Multiple Regression Analysis}

The multiple regression analysis in this study regarding the effect of perceived quality, perceived risk, store image, product packaging and familiarity on the purchase intention of grocery's private label "Giant" can be seen in table I. below: 
TABLE I. MULTIPLE REGRESSION ANALYSIS

\begin{tabular}{|c|c|c|c|c|c|c|}
\hline \multirow[t]{2}{*}{ Variabel } & \multicolumn{2}{|c|}{$\begin{array}{l}\text { Unstandardized } \\
\text { Coefficients }\end{array}$} & \multirow[b]{2}{*}{$\mathbf{t}$} & \multirow{2}{*}{ Sig } & \multirow[b]{2}{*}{ table } & \multirow[b]{2}{*}{ Remarks } \\
\hline & B & Std.error & & & & \\
\hline Constant & -0.743 & 1.242 & - & - & & \\
\hline Perceived Quality & 0.109 & 0.044 & 2.463 & 0.015 & 1.972 & Accepted \\
\hline Perceived Risk & 0.597 & 0.064 & 9.251 & 0.000 & 1.972 & Accepted \\
\hline Product Packaging & 0.012 & 0.042 & 0.286 & 0.775 & 1.972 & Rejected \\
\hline Store Image, & 0.115 & 0.057 & 2.025 & 0.044 & 1.972 & Accepted \\
\hline Familiarity & 0.177 & 0.067 & 2.649 & 0.009 & 1.972 & Accepted \\
\hline \multicolumn{2}{|l|}{$R$} & \multicolumn{4}{|c|}{0.664} & \\
\hline \multicolumn{2}{|l|}{$R$ square } & \multicolumn{4}{|c|}{0.441} & \\
\hline Adjusted $R$ square & & & & & & \\
\hline
\end{tabular}

The results of the test can be seen in the table above, explained as follows;

Based on the results of the regression test that has been done, the significance results for the variable are perceived quality is 0.015 while the hypothesis decisionmaking requirements are significance $<0.05$ or $t$ count $<\mathrm{t}$ table. The result of perceived quality is $0.015<0.05$, which means there is a significant influence between perceived quality on purchase intention. These results support previous research, such as [2], [27].

Based on the calculation of the regression test results obtained significance for the variable perceived risk of $0.000<0.05$ or seen from $\mathrm{t}$ arithmetic of $9.251>\mathrm{t}$ table (1.972). So it can be said that there is a significant influence between the variable perceived risk with purchase intention. These results support previous research, such as[28], [29].

Based on the calculation of the regression test results obtained significance results of $0.775>0.05$ or $t$ arithmetic (0.286) <t table (1.972) which means there is no significant influence between the variable product packaging with purchase intention. These results are not in accordance with previous studies such as [16], [30], [31].

Based on the calculation of the regression results obtained significance for the variable store image of 0.044 or sig $<0.05$. While the results of $t$ count $>t$ table 2.025> 1.972 so it can be concluded that there is a significant influence between the variable store image with purchase intention. results support previous research, such as (Konuk, 2018; Ramadhan and Muthohar, 2019; Pinem et al., 2019).

Based on the calculation of the regression results obtained significance for the variable familiarity of 0.009 $<0.05$ and seen from $t$ arithmetic $>t$ table 2.649> 1.972 which means that there is a significant influence between familiarity and purchase intention. results support previous research, such as [32], [33]

\section{CONCLUSIONS AND RECOMMENDATIONS}

Based on the results of research and data analysis, the conclusions drawn from the title of the research "Antecedents of purchase intention towards grocery's private label product" giant (studies on giant express gresik district) "are as follows: Perceived quality has a positive and significant effect on purchase intention grocery's private label product, perceived risk has a positive and significant effect on purchase intention grocery's private label product, Product packaging has a positive and not significant effect on purchase intention grocery's private label product, Store Image has a positive and significant effect on purchase intention grocery's private label product, and finally Familiarity has a positive and significant effect on grocery's private label purchase intention.

Based on the results of research, discussion, and conclusions, the researcher can recommend in several aspects. Managerial aspects, first; From aspects of perceived quality, perceived risk, store image and familiarity that affect private label purchase intentions, retail managers must improve quality in terms of composition and others so that consumers who have already purchased even repurchase products private label. Secondly, in the variable aspect of product packaging, retail managers should provide more attractive designs so that visitors or consumers are interested in packaging so that they appear interested in buying, especially Grocery's private label products. Implications of future research, the results of this study can be used as a reference for future researchers by adding mediation variables and by using different analysis techniques such as the PLS (partial least square) analysis model and adding other variables such as price perceptions and promotions due to Adjusted values R Square.

\section{REFERENCES}

[1] N. Kumar and J.-B. E. M. Steenkamp, "Brand versus Brand," Int. Commer. Rev., vol. 7, no. 1, pp. 46-53, 2007.

[2] F. A. Konuk, "The role of store image, perceived quality, trust and perceived value in predicting consumers' purchase intentions towards organic private label food," J. Retail. Consum. Serv., vol. 43, no. April, pp. 304-310, 2018.

[3] R. Sethuraman and C. Cole, "Factors influencing the price premiums that consumers pay for national brands over store brands," J. Prod. Brand Manag., vol. 8, no. 4, pp. 340-351, 1999.

[4] C. Calvo Porral and J. P. Levy-Mangin, "Food private label brands: the role of consumer trust on loyalty and purchase intention," Br. Food J., vol. 118, no. 3, pp. 679-696, 2016.

[5] N. Norfarah, P. M. Koo, and A. K. Siti-Nabih, "Private Label Brand Purchase Intention: A Malaysian Study," Glob. Bus. Manag. Res. An Int. J. VO - 10, vol. 10, no. 1, p. 197, 2018.

[6] G. Muruganantham and K. Priyadharshini, "Antecedents and consequences of private brand purchase: A systematic review 
and a conceptual framework," Int. J. Retail Distrib. Manag., vol. 45, no. 6, pp. 660-682, 2017.

[7] P. C. S. Wu, G. Y. Y. Yeh, and C. R. Hsiao, "The effect of store image and service quality on brand image and purchase intention for private label brands," Australas. Mark. J., vol. 19, no. 1 , pp. 30-39, 2011 .

[8] V. A. Zeithaml, "Consumer Perceptions Of Price , Quality , And Value: A Means," J. Mark., vol. 52, no. 3, p. 2, 1988.

[9] T. Girard, P. Trapp, M. Pinar, T. Gulsoy, and T. E. Boyt, "Consumer-Based Brand Equity of a Private-Label Brand: Measuring and Examining Determinants," J. Mark. Theory Pract., vol. 25, no. 1, pp. 39-56, 2017.

[10] S. Sukaris, S. Hartini, and D. Mardhiyah, "Increasing Electronic Word-of-Mouth Activities through Self-Congruity and Tourist Values," Int. J. Innov. Creat. Chang., vol. 9, no. 10, pp. 162$183,2019$.

[11] S. Hartini, D. Mardhiyah, and Sukaris, "A conceptual framework for relationship between symbolic risk consumption with electronic word of mouth," Opcion, vol. 36, no. Special Edition 26, pp. 1282-1295, 2020.

[12] U. P. Jaidev and D. Dhanya, "Antecedents of Customer Attitude and Purchase Intention towards Private Label Food Brands," in National Conference on Marketing and Sustainable Development, 2018, no. September 2017, pp. 428-448.

[13] G. R. Dowling, "Perceived Risk: The Concept and Its Measurement," Perceived Risk Concept Its Meas., vol. 3, no. 3, pp. 193-210, 1986.

[14] L. Hollywood, L. Wells, G. Armstrong, and H. Farley, "Thinking outside the carton: Attitudes towards milk packaging," Br. Food J., vol. 115, no. 6, pp. 899-912, 2013.

[15] T. Madden, K. Hewett, and M. Roth, "Managing Images in Different Cultures: A Cross-National Study of Color Mean...: Discovery Service para Universidad De La Sabana," J. Int. Mark., vol. 8, no. 4, pp. 90-107, 2000.

[16] M. Poturak, "Influence of Product Packaging on Purchase Decisions," Eur. J. Soc. Hum. Sci., no. 3 (3), pp. 144-150, 2014.

[17] R. Kuvykaite, A. Dovaliene, and L. Navickiene, "Impact of package elements on consumer's purchase decision," Econ. Manag., vol. 14, pp. 441-447, 2009.

[18] K. B. Hartman and R. L. Spiro, "Recapturing store image in customer-based store equity: A construct conceptualization," $J$. Bus. Res., vol. 58, no. 8, pp. 1112-1120, 2005.

[19] D. Grewal, R. Krishnan, J. Baker, and N. Borin, "The effect of store name, brand name and price discounts on consumers' evaluations and purchase intentions," J. Retail., vol. 74, no. 3, pp. 331-352, 1998.

[20] J. J. Beristain and P. Zorrilla, "The relationship between store image and store brand equity: A conceptual framework and evidence from hypermarkets," J. Retail. Consum. Serv., vol. 18, no. 6, pp. 562-574, 2011.

[21] R. J. Pinem, D. Purbawati, A. Srifitriani, S. Wahyoedi, and Sukaris, "Green companies and the millennial generation as the spearhead of the environment," Int. J. Innov. Creat. Chang., vol. 8, no. 2, pp. 106-115, 2019.

[22] J. W. Alba and J. W. Hutchinson, "Dimensions of Consumer Expertise," J. Consum. Res., vol. 13, no. 4, p. 411, 1987.

[23] D. Gefen, "E-commerce: The role of familiarity and trust," Omega, vol. 28, no. 6, pp. 725-737, 2000.

[24] J. F. Hair, W. C. Black, B. J. Babin, and R. E.anderson, Multivariate Data Analysis. 2014.

[25] J. A. Gliem and R. R. Gliem, "Calculating, Interpreting, and Reporting Cronbach's Alpha Reliability Coefficient for LikertType Scales," Midwest Res. to Pract. Conf. Adult, Contin. Community Educ., 2003.

[26] N. K. Maholtra, Marketing Research: An Applied Orientation, no. 1.1996.

[27] M. D. Ramadhan and M. Muthohar, "The influence of perceived price, perceived quality, brand image, and store image on the purchase intention of Hypermart private label," Adv. Soc. Sci. Educ. Humanit. Res., vol. 308, no. Insyma, pp. 140-143, 2019.

[28] E. J. M. Arruda Filho, J. D. S. Simões, and C. F. De Muylder, "The low effect of perceived risk in the relation between hedonic values and purchase intention," J. Mark. Manag., vol.
36, no. $1-2$, pp. $128-148,2020$.

[29] C. Bianchi and L. Andrews, "Risk, trust, and consumer online purchasing behaviour: A Chilean perspective," Int. Mark. Rev., vol. 29 , no. 3, pp. 253-275, 2012.

[30] S. Hussain, M. Ibrahim, and A. Noreen, "Impact of Product Packaging on Consumer Perception and Purchase Intention," $J$. Mark. Consum. Res., vol. 10, no. 2011, pp. 1-10, 2015.

[31] A. H. de L. Jos Akkermans, "Consumers' perception of usability of product packaging and impulse buying: considering consumers' mood and time pressure as moderating variables," Eletronic Libr., vol. 34, no. 1, pp. 1-5, 2018.

[32] E. D. Augusta, D. Mardhiyah, and T. Widiastuti, "Effect of country of origin image, product knowledge, brand familiarity to purchase intention Korean cosmetics with information seeking as a mediator variable: Indonesian women's perspective," Dermatology Reports, vol. 11, no. S1, pp. 7-10, 2019.

[33] G. Das, "Linkages between self-congruity, brand familiarity, perceived quality and purchase intention: A study of fashion retail brands," J. Glob. Fash. Mark., vol. 6, no. 3, pp. 180-193, 2015 . 